\title{
Time-Varying Conditional Profitability of Momentum Strategies in Commodity Futures Market: Evidence from India
}

\author{
Ritika Jaiswal* and Rashmi Uchil
}

\begin{abstract}
Manuscript type: Research paper

Research aims: This study aims to provide fresh evidence on the presence of momentum profitability in the commodity futures market of India.

Design/Methodology/Approach: The sample of this study consists of highly traded commodity futures contracts taken from the commodity market of India over the period of 2006-2017. This study applies the conditional multi-factor model to test the time-varying performance of the momentum strategies.

Research findings: This study confirms the existence of exceptionally high abnormal momentum profitability in the commodity futures market despite the consideration of transaction costs. However, subsample analysis and the application of conditional multi-factor model suggest that momentum profits are essentially time-varying. The low and insignificant correlation of momentum portfolios with stocks and bonds confirm that the relative strength of the momentum portfolios of commodity futures are part of an effective strategy to create a welldiversified portfolio.

Theoretical contribution/Originality: This study examines the timevarying conditional profitability of momentum strategies for the commodity futures market of emerging economies such as India.
\end{abstract}

* Corresponding author: Ritika Jaiswal is an Assistant Professor at the Department of Economics, BITS Pilani, K K Birla Goa Campus, NH 17 B, Zuarinagar, Goa, India 403726. E-mail: ritikastone@gmail.com

Rashmi Uchil is an Assistant Professor at the School of Management, NITK, Srinivasanagar, PO, Surathkal, Mangalore, Karnataka, India 575 025. E-mail: rashmi.suchil@gmail.com

https:// doi.org/10.22452/ajba.vol13no2.9 
The outcome enriches the small group of contemporary studies that have been conducted on commodity futures in relation to India. The most significant contribution of this study is the use of a conditional multi-factor model which assesses the possible role of time-varying conditional alphas and betas in defining the momentum payoffs in the commodity futures market in India.

Practitioner/Policy implication: Policymakers should consider developing more lucrative policies which can attract institutional investors to the commodity market of India. This is because the domestic and foreign institutional investors are central to the enhancement and stability of the financial market. It is imperative to create awareness about the exceptionally high abnormal profits generating potential of the commodity futures that are used by professional money managers simply as a tool for price risk management.

Research limitations: This study uses 13 highly traded commodity futures contracts of India to design the momentum strategies. The robustness of the high abnormal returns provided by these strategies can be further investigated through an extended study period, and by including medium and less liquid commodity futures contracts to create the momentum strategies.

Keywords: Commodity Market, CCIL Bond Index, Conditional Multi-Factor Model, Momentum Strategy, Transaction Cost, TimeVarying Risk

JEL Classification: G10, G11, G12, G13

\section{Introduction}

Securing a stable and abnormal returns from investments is the primary concern of every investor, and any traditional or alternative asset manager. Many of these investors are using commodity futures as an investment vehicle for making strategic and tactical allocations. Strategic allocations of commodity futures are highly valued due to the benefits of the long-term equity-like returns, the diversification benefits, and the inflation hedging potentials (Bodie \& Rosansky, 1980; Jensen, Johnson \& Mercer, 2002; Erb \& Harvey, 2006; Gorton \& Rouwenhorst, 2006; Jaiswal \& Uchil, 2016; 2018a; 2018b). In addition to the strategic asset allocations, commodity futures are used for tactical asset allocations to generate abnormal alphas as shown by previous studies (Erb \& Harvey, 2006; Miffre \& Rallis, 2007). Of the various active strategies used for tactical asset allocations, the most ubiquitous one is momentum strategy. Momentum strategies are implemented by buying commodity futures 
that outperform the market with the superior historical return, and shorting the commodity futures that underperform with the lowest returns (Miffre \& Rallis, 2007). These strategies are based on the ideology that assets with positive returns over the past year will continue to do so in the future (Jegadeesh \& Titman, 1993).

The present study investigates the abnormal profit potential of 24 momentum strategies that were designed by using 13 highly traded futures contracts of the Indian commodity market. The selection of the highly liquid futures contracts was motivated by the perception that momentum strategies perform better with a liquid market state in contrast to illiquidity (Page, Britten \& Auret, 2013; Avramov, Cheng $\&$ Hameed, 2016). The results confirmed the profitability of four momentum strategies, with a ranking period of one month, and a holding period of 6, 12, 18 and 24 months. These strategies generated an average monthly return of 7.17 per cent (an average annualised return of 58.03 per cent). These returns were considered abnormally high when compared to the annualised returns of 9.38 per cent reported by Miffre and Rallis (2007). The primary driving force of the exceptionally high and abnormal profitability of the momentum strategies can be traced to the liquidity of the futures contracts, and the bull phase of 20072010 (Cheng \& Xiong, 2014; Canuto, 2014; Sarhan, 2016). The outcome was clearly depicted by the sub-sample analysis which showed that profitable momentum strategies for the sub-periods, September 2006 to March 2010, April 2010 to October 2013, and November 2013 to April 2017, had yielded an average monthly return of 25.97 per cent, 4.14 per cent, and 4.07 per cent, respectively. The reduced profitability of momentum strategies in the latter sub-periods was due to the downward trend of the commodity markets which occurred in mid2012 to 2015. This phenomenon confirmed that the commodity cycle directly impacted the momentum profitability. The outcome was, however, contrary to Miffre and Rallis (2007), who used the dataset spanning from 1979 to 2004, which had lacked the bull phase of the commodity cycle.

The results of this study also revealed that the presence of price reversals in the dataset had caused past losers to gain more than the past winners. This showed that the loser portfolios outperformed the winner portfolios. The finding thus contradicted the outcomes of previous studies, such as Rouwenhorst (1998) and Miffre and Rallis (2007), who had noted that the winner portfolios outperformed the loser portfolios. Nonetheless, the results showed that the commodity-based momentum 
portfolios can be utilised to create a diversified portfolio because of the low and insignificant correlation with other asset classes, such as stocks and bonds.

The robustness of the results obtained in the present study was verified by the sensitivity analysis. First, the results confirmed that different approaches of compiling the future price series have a significant influence on the profitability of the momentum payoffs. Second, the consistency of the momentum profits in the futures was verified by implementing the momentum strategies in different time frames. Third, the net momentum returns were reported by including the transaction costs which were estimated based on the conservative estimates provided by Locke and Venkatesh (1997), and Shen, Szakmary and Sharma (2007). Finally, based on the work of Chordia and Shivakumar (2002), the conditional multi-factor model was used to examine the impact of the vector of the lagged macroeconomic variables on the abnormal performance of the momentum strategies.

The present study contributes to the existing research in several ways. First, the extended study period used in this study encompassed the bull phase of 2007 to 2010, a period considered to be a major turnaround in the history of the commodities market In contrast to previous studies (Erb \& Harvey, 2006; Miffre \& Rallis, 2007; Fuertes, Miffre \& Rallis, 2010), an extended study period contributes to the analysis of the time-varying performance of the momentum strategies, thereby confirming that exceptionally high abnormal returns of the momentum strategies were essentially time-varying. Second, highly liquid contracts were used to design the momentum strategies, and results confirmed the significant role of these contracts to the exceptionally high abnormal returns of the momentum strategies. This finding therefore provides fresh evidence to the literature looking at the association between market liquidity and momentum returns (Tan \& Cheng, 2019; Page et al., 2013; Avramov et al., 2016). Finally, this study expands on current studies by analysing the profitability of the momentum strategies for the commodity market of emerging economies such as India. The current study is probably the first of its kind to incorporate the conditional multi-factor model in analysing the timevarying aspect of the momentum strategies in the context of India.

The remainder of this paper is structured as follows. Section 2 discusses past studies related to the implementation of momentum strategies in diverse markets. Sections 3 and 4 elaborate on the data and methodology used for the study. Section 5 discusses the implementation 
of the strategies and the interpretation of the results. Section 6 draws a conclusion and expounds on the direction of future research.

\section{Literature Review}

The fundamental rule of momentum strategy is to long the past winners and to short the past losers which then causes the prices to overreact due to the temporary price reversal from their long-run values. Numerous studies have been conducted to examine the momentum strategies in international equity markets. For instance, Jegadeesh and Titman (1993) found that strategies which buy past winner stocks, and sell past loser stocks during the period of 1965 to 1989 earned a significant abnormal return. The strategy was based on the ranking and holding period of six months which provided an annualised excess profit of 12.01 per cent; it lasted on an average of one year. Similar results were observed in Rouwenhorst (1998), who studied 12 European countries for the sample period of 1980 to 1995 . He too found that the portfolios of past winners outperformed the past losers. This return continued for approximately one year after accounting for risks.

The findings of Jegadeesh and Titman (1993) were not limited to the market of the United States alone. Similar results were noted by other researchers in different markets. For example, Chui, Titman and Wei (2010) revealed that the magnitude of momentum profits was influenced by cultural differences and individualism. They reported that the Asian stock markets had superior momentum returns, except for Japan. Van der Hart, Slagter and Van Dijk (2003) confirmed the generation of significant excess returns when using momentum strategies in 32 emerging markets over the period of 1985 to 1999. Fama and French (2012) found that momentum profitability was present in Europe, North America, and the Asian-Pacific countries, except for Japan. Chaves (2012), and Asness, Moskowitz and Pedersen (2013) detected significant momentum returns in Japan and eight diverse markets. This posed a challenge for the asset pricing theories that concentrated primarily on the US equities. Lobão and Lopes (2014) also ascertained that significant positive returns were delivered by momentum strategies during the holding period of three to 12 months in the Portuguese stock market.

A growing body of research has supported the presence of momentum returns in diverse equity markets. While several causes of momentum profitability had been uncovered in literature, there is still a lack of consensus on the source of its existence in the equity market 
Along this line, Grundy and Martin (2001), and Korajczyk and Sadka (2004), observed that momentum in the stocks return cannot be defined as a reward due to exposure to the different risk factors. Barberis, Shleifer and Vishny (1998), and Daniel, Hirshleifer and Subrahmanyam (1998), similarly showed that momentum returns in the equity market were the result of investors' cognitive biases related to under-reaction and over-reaction to the news. Lee and Swaminathan (2000) had proven that trading volumes which represent the demand for a stock can be used to determine the persistence, and the magnitude of future price momentum. This was endorsed by Hong, Lim and Stein (2000) who reported that stocks with low analyst coverage provided superior momentum returns which declined sharply with firm size. In contrast, Johnson (2002) found that momentum profitability in the equity market was due to the time-varying risk factors, such as dividend growth rates. Similarly, Chordia and Shivakumar (2002) also asserted that lagged macroeconomic variables, such as dividend yields, term structures, and others can explain the momentum profits. Consequently, Li, Miffre, Brooks and O'Sullivan (2008) proposed that momentum profits can be eroded by time-varying unsystematic risks or by the cost of implementing the momentum strategies (Keim, 2003). Nonetheless, Griffin, Ji and Martin (2003) noted that momentum profits cannot be explained by macroeconomic variables, hence momentum profits can be considered as independent of negative and positive economic growth, both in the US and other countries.

Little studies have been done to assess the momentum returns premia in the commodity futures market even though several benefits can be gained by implementing momentum strategies in the commodity futures market. Thus, it is hoped that the current study would offer the following contributions. First, implementing momentum strategies in the commodity futures market would involve very low transaction costs ( 0.0004 per cent to 0.033 per cent) in comparison to the equity market (Locke \& Venkatesh, 1997; Marshall, Nguyen \& Visaltanachoti, 2012). This was also revealed by Shen et al. (2007) who engaged the estimates of the bid-ask spreads proposed by Locke and Venkatesh (1997) to examine the additional transaction costs of $\$ 10$ per contract. It was estimated that the transaction costs ranged from a low of 0.044 per cent to a high of 0.146 per cent. Likewise, Lesmond, Schill and Zhou (2004) also noted that the trading costs related to the implementation of momentum strategies in the stocks market were much higher as the composition of the momentum portfolio was skewed towards 
trading in high transaction cost stocks. Second, momentum strategies trade on most liquid nearby contracts. Unlike the stock market, short selling restriction does not hamper the implementation of momentum strategies in the commodity futures market (Miffre \& Rallis, 2007; Shen et al., 2007; Lesmond et al., 2004). Third, this study used the sample of 13 commodity futures contracts to construct the momentum strategy. The result developed a less trading intensity as compared to the hundreds or thousands of stocks in the equity market

The existence of momentum profitability in the commodity futures market has been confirmed by previous studies. For instance, Erb and Harvey (2006) created the relative strength portfolios by holding a long position in the winner portfolios with positive returns in the last one year, and by taking a short position in the past loser portfolios with negative returns. The portfolios generated the highest excess return of 10.8 per cent, and the highest Sharpe ratio of 0.55. Additionally, Shen et al. (2007) noted that momentum strategies for short and intermediate time periods have offered returns closest to the returns reported in stocks. Likewise, Miffre and Rallis (2007), Fuertes et al. (2010), Narayan, Ahmed and Narayan (2015), and Gorton, Hayashi and Rouwenhorst (2013) also endorsed that momentum strategies in the commodity futures market offer a significant abnormal alpha. In another study, Moskowitz, Ooi and Pedersen (2012) found a significant momentum performance in the equity, currency, bond, and commodity futures. This finding was consistent with the sentiment theories of initial underreaction and delayed over-reaction. Bianchi, Drew and Fan (2015) then proposed that 'microscopic momentum', which disintegrates the intermediate time-horizon momentum into single-month momentum components, generated consistent economic profits. Further to this, Zaremba (2016) offered evidence confirming the existence of momentum profitability in the commodity futures markets. However, he also indicated that the level of momentum profitability was lower in the market of high financialisation. In relation to India, Sharma, Ramana, Thaker and Rastogi (2014) have analysed the profitability of the momentum strategy of the ranking and holding period of one month, using, the Markowitz mean-variance optimisation technique, for the period of 2004 to 2012. Their results confirmed that the allocation of commodity futures to a traditional portfolio using momentum and term structure strategies, produced a superior risk-adjusted return. However, they did not analyse the time-varying risk-adjusted return performance of the momentum strategies. 
This showed an evident lack of available research which examined the existence of time-varying momentum profitability in the Indian context. Hence, the current study endeavours to bridge this gap.

\section{Data}

The study focussed on 13 highly traded commodity futures contracts of the Multi Commodity Exchange (MCX) which leads the market share in India. It carries a market share of 93.4 per cent in terms of the value of the traded commodity futures contracts in India. The monthly prices of the commodity futures contracts, viz. crude oil, natural gas, gold, silver, copper, zinc, aluminium, lead, nickel, crude palm oil (CPO), cardamom, cotton and mentha oil, were applied for the period of June 2006 to April 2017. These commodity futures contracts played a significant role in the Indian economy; they were also deemed to be the most liquid futures contracts in terms of their average annual physical market value, and total turnover. In addition, they absorbed the highest market shares of the commodity futures trading at MCX, in terms of value and volume of trading. These commodity futures contracts were also the constituents of the MCXCOMDEX, India's real-time composite commodity index. It is used as a barometer for the commodity futures prices movement, and is considered an indicator of the overall commodity market trend for the country's economy. Hence, the overall trend of the commodity futures market of India can be tracked by using these commodity futures contracts. The MCXCOMDEX is the simple weighted average of the group indices - MCXAGRI, MCXMETAL and MCXENERGY. The weights of the constituents of these group indices were determined based on their physical market size, and their liquidity on the exchange. Values of Nifty, a leading stock market index in India and the Clearing Corporation of India Ltd.'s (CCIL) liquid total returns bond index was extracted from the National Stock Exchange and CCIL, respectively. The Wholesale Price Index (WPI) was chosen as an inflation index instead of the Consumer Price Index (CPI) because the aforementioned commodities were not included in the CPI in India.

This study adopts three different approaches to formulate the futures price series in order to evaluate the sensitivity of the momentum returns. Continuously compounded logarithmic returns were utilised to determine the futures return for all the three approaches. First, the nearby most actively traded futures contracts were used to construct the future price series. The first nearby contract was held for one 
month before maturity. Considering the rolling mechanism adopted by MCX, the series from the first nearby contract were rolled over to the second nearby contract at the end of every month. This contract was subsequently, held for one month before maturity. The same procedure is rolled forward to formulate the series of futures returns.

Second, the same procedure was repeated for the second approach with a slight difference. Instead of the second nearby contract, the most distant contract was used to compile the futures price series.

Third, the rolling date was changed from the end of the month to the 15th of the maturity month. If trading was not done on the 15th, then the trading date previous to the 15th was considered for the formation of the futures price series. This sensitivity analysis helped to scrutinise the impact of the liquidity risk; it also helped to modify the rolling date on the momentum profits due to the inclusion of nearby maturing contracts and distant maturity contracts. It is customary to consider that a lack of liquidity in the distant maturity contract would lead to a negative impact on the momentum profits (Miffre \& Rallis, 2007). However, liquidity risk can be compensated by abnormal profits which are generated due to trading in the distant maturity contracts, if momentum profits follow the Theory of Normal Backwardation as propagated by Keynes (1930), Hicks (1939), Kolb (1992) and Miffre (2000).

\section{Methodology}

Following the steps of Jegadeesh and Titman (1993, 2001), and Miffre and Rallis (2007), this study analysed the momentum payoffs for the different combinations of Ranking (R) periods (1, 3, 6 and 12 months), and Holding $(\mathrm{H})$ periods $(1,3,6,12,18$ and 24 months). The study assessed the 24 momentum strategies for the combination of $\mathrm{R}-\mathrm{H}$, such as 1-1, 1-3, 1-6, 1-12, 1-18, 1-24, 3-1, 3-3, 3-6, 3-12, 3-18, 3-24, 6-1, 6-3, 6-6, $6-12,6-18,6-24,12-1,12-3,12-6,12-12,12-18$ and 12-24. The returns of the 3-6 momentum strategy were based on the previous three months' average return (i.e. a Ranking period of three months) which was held for the next six months (i.e. a Holding period of 6 months).

Jegadeesh and Titman $(1993,2001)$ have classified futures contracts into deciles by considering their average returns during the previous $\mathrm{R}$ months. Due to the limited cross section, Miffre and Rallis (2007) created the quintiles at the end of each month based on the average returns over the previous $\mathrm{R}$ months. However, the current study adopts a slightly different strategy in order to create the winner and loser portfolios. Due 
to the small study period, and the limited cross section, the commodity futures contracts used in the current study were divided into only two portfolios - winner and loser portfolios. This is based on their positive and negative returns as noted in the previous $\mathrm{R}$ months. For both portfolios, equal weights were assigned to the respective commodity futures. Based on their performance in the subsequent $\mathrm{H}$ months, the $\mathrm{R}-\mathrm{H}$ momentum strategy which buys the winner portfolio and shorts the loser portfolio was constructed.

Following the approach of Moskowitz and Grinblatt (1999), Jegadeesh and Titman (2001), and Miffre and Rallis (2007), the overlapping winner and loser portfolios were created. For instance, for the 3-6 momentum strategy, the return of the winner portfolio in July was the sum of the previous six overlapping positive returns portfolios. These six overlapping portfolios were formed at the end of January (ranking period from October to December return), February (ranking period from November to January return), March (ranking period from December to February return), April (ranking period from January to March return), May (ranking period from February to April return) and June (ranking period from March to May return). A similar approach was applied for estimating the returns of the loser portfolio in July which was the average return of the six overlapping negative returns portfolios created at the end of January, February, March, April, May, and June. Finally, the returns of the momentum strategy, 3-6 for the month of July was estimated by subtracting the July returns of the loser portfolios from the returns of the winner portfolios. A similar procedure was followed to estimate the momentum payoffs for the subsequent months. The riskadjusted returns of the momentum strategy were estimated by using the multifactor model, as shown in Equation (1).

$$
\begin{aligned}
R_{M t} & =\alpha+\beta_{S}\left(R_{S t}-R_{f t}\right)+\beta_{B}\left(R_{B t}-R_{f t}\right)+\beta_{C}\left(R_{C t}-R_{f t}\right)+\varepsilon_{M t} \\
t & =1, \ldots \ldots, T
\end{aligned}
$$

where, $R_{M t}$ is the returns of the winner, loser and momentum portfolios. $R_{S t}, R_{B t}$ and $R_{C t}$ represent the log returns of Nifty index, CCIL total returns bond index and the MCXCOMDEX composite index. $R_{f t}$ and $\varepsilon_{M t}$ show the risk-free rate, and the error term, respectively. The three-month Treasury bill rate was taken as a risk-free rate.

Unconditional alphas and betas were estimated through the unconditional multifactor model, noted in Equation (1) which provided an incorrect performance evaluation of the momentum strategies if the 
momentum payoffs were a compensation for the time-varying risks (Chordia \& Shivakumar, 2002). Ferson and Schadt (1996) thus proposed a conditional model in which the betas served as the linear function of the vector of pre-specified information variables $Z_{t-1}$ as shown in Equation (2). Information variable $Z_{t-1}$ represents the publicly available information at time $t-1$ which reflects the different business cycles.

$$
\beta_{P}\left(Z_{t-1}\right)=\beta_{P 0}+\beta_{P 1} z_{t-1}
$$

where, $z_{t-1}$ is the vector of the deviation of the individual information variables $Z_{t-1}$ from their unconditional mean value. $\beta_{P 1}$ is the conditional beta which measures the impact of the information variables on the conditional beta. $\beta_{P 0}$ is the unconditional beta which is the unconditional mean of the conditional beta.

Extending on the model of Ferson and Schadt (1996), Christopherson, Ferson and Glassman (1998) proposed a model for the explicit time-varying conditional alpha. Like the conditional beta, the conditional alpha is the linear function of a vector of pre-specified information variables $z_{t-1}$ as shown in Equation (3).

$$
\alpha_{P}\left(Z_{t-1}\right)=\alpha_{P 0}+\alpha_{P 1} z_{t-1}
$$

where $\alpha_{P 0}$ is the unconditional average alpha and $\alpha_{P 1}$ measures the impact of the information variables on the conditional alpha. The conditional single factor model with time-varying alphas and betas is shown in Equation (4) which is the combination of Equations (2) and (3) (Leite, Cortez \& Armada, 2009).

$$
R_{P t}=\alpha_{P 0}+\alpha_{P 1} z_{t-1}+\beta_{P 0} R_{m t}+\beta_{P 1}\left(z_{t-1} R_{m t}\right)+\varepsilon_{P t}
$$

where $R_{P t}$ represents the excess return of portfolio $P$ over period $t . R_{m t}$ is the markets' excess return during the same time period.

The conditional multifactor model which measures the timevarying beta and alpha (abnormal performance) of momentum strategies as a linear function of the information variable $Z_{t-1}$ is shown in Equation (5) (Miffre \& Rallis, 2007).

$$
\begin{aligned}
R_{P t}= & \alpha_{P 0}+\alpha_{P 1} z_{t-1}+\beta_{S 0}\left(R_{S t}-R_{f t}\right)+\beta_{S 1}\left(R_{S t}-R_{f t}\right) z_{t-1}+ \\
& \beta_{B 0}\left(R_{B t}-R_{f t}\right)+\beta_{B 1}\left(R_{B t}-R_{f t}\right) z_{t-1}+\beta_{C 0}\left(R_{C t}-R_{f t}\right)+ \\
& \beta_{C 1}\left(R_{C t}-R_{f t}\right) z_{t-1}+\varepsilon_{P t}
\end{aligned}
$$

where $\beta_{S 0}, \beta_{B 0}$ and $\beta_{C 0}$ are the unconditional betas of the Nifty stock index, CCIL bond index, and the MCXCOMDEX index, respectively. $\beta_{S 1}, \beta_{B 1}$ 
and $\beta_{C 1}$ represent the conditional betas. The insignificant values of the unconditional alpha $\left(\alpha_{0}\right)$ in equation (5) indicates that time-varying risk compensates the abnormal returns of the momentum strategies which follow the market efficiency of the semi-strong form provided by Fama (1970).

The information variables $\left(Z_{t-1}\right)$, represent the proxy for the business cycle; it includes the first lag of following the information variables: onemonth Mumbai Inter-bank offer rate, the dividend yield on the Nifty 50 stock index, and the term structure of interest rates. The term structure is estimated as a difference between the ten-year Indian Treasury bond yield, and the three-month Treasury-bill rate. In order to validate the model shown in Equation (5), it is essential that the following hypotheses be rejected (Miffre \& Rallis, 2007):

First, Conditional Alpha $\left(\alpha_{1}\right)=0$,

Second, Conditional Beta $\left(\beta_{1}\right)=0$

Third, $\alpha_{1}=\beta_{1}=0$

The transaction cost is estimated based on the works of DeMiguel, Garlappi and Uppal (2009), Daskalaki and Skiadopoulos (2011), and Fuertes et al. (2010). The portfolio turnover is estimated to know the amount of trading required for implementing the momentum strategies. Hence, the portfolio turnover $P T_{m}$ for a strategy $m$ is the average absolute change in the weights across the $N$ number of assets, and over the $T-1$ rebalancing points in the time estimated, by using Equation (6) (DeMiguel et al., 2009; Kostakis, Panigirtzoglou, \& Skiadopoulos, 2011).

$$
P T_{m}=\frac{1}{T-1} \sum_{t=1}^{T-1} \sum_{J=1}^{N}\left(\left|w_{m, j, t+1}-w_{m, j, t^{+}}\right|\right)
$$

where $w_{m, j, t+1}$ and $w_{c, j, t^{+}}$are the optimal weights of asset $j$ for strategy $m$ at time $t$ and $t+1$, respectively. The value of $\left|w_{m, j, t+1}-w_{c, j, t^{+}}\right|$shows the absolute change in weights for asset $j$ at the $t+1$ rebalancing point. The net momentum return is computed for the realized portfolio return $M R_{m, p, t+1}$ at $t+1$ by using the estimated transaction costs $(t c)$ of 0.033 per cent of Locke and Venkatesh (1997), and 0.146 per cent of Shen et al. (2007), as shown in Equation (7).

$$
N W_{m, t+1}=N W_{m, t}\left(1+M R_{m, p, t+1}\right)\left[1-t c * \sum_{j=1}^{N}\left(\left|w_{m, j, t+1}-w_{m, j, t^{+}}\right|\right)\right.
$$

where $N W_{m, t+1}$ and $N W_{m, t}$ are the net of transaction costs wealth for strategy $m$ at $t$ and $t+1$. Hence, the return, the net of transaction costs 
$N M R_{m, t+1}$, is estimated by using Equation (8).

$$
N M R_{m, t+1}=\frac{N W_{m, t+1}}{N W_{m, t}}-1
$$

\section{Results and Discussions}

The performance evaluation of the relative strength of the momentum strategies is presented in the subsequent sections.

\subsection{Momentum Profits}

The performance evaluation of the momentum payoffs was analysed from the perspective of their sub-samples, and the sensitivity analysis.

\subsubsection{Momentum Profits for Whole Sample}

The mean, standard deviation, and risk-adjusted return performance, i.e. the Sharpe ratios of all the momentum strategies, are shown in Table 1. The results indicate that the profits of four momentum strategies of the ranking period of one month, and the holding period of six, 12, 18 and 24 months were positive and significant. These four momentum strategies provided the average monthly return of 7.17 per cent, and an annualised return of 58.03 per cent. This was achieved by consistently buying the commodity futures with past positive returns, and selling the commodity futures with negative returns. In contrast, the long-only passive investment in the composite commodity, the stocks and bonds index yielded an annualised return of 4.76 per cent, 10.29 per cent, and 8.30 per cent, respectively. In line with the findings of previous studies (Erb \& Harvey, 2006; Miffre \& Rallis, 2007; Fuertes et al., 2010), the results confirmed that tactical asset allocations which utilised momentum strategies produced the highest returns as compared to the long-only passive strategies.

Nine momentum strategies of the ranking periods of three, six and 12 months which yielded negative and significant results, are depicted in Figure 1. The negative returns of the momentum strategies were primarily due to the positive returns provided by the loser portfolios for the respective ranking periods. This indicates the presence of a price reversal pattern in the dataset. In addition, the momentum strategy (124 ) with the ranking period of one month, and the holding period of 24 months, was found to be more profitable; it provided the highest 


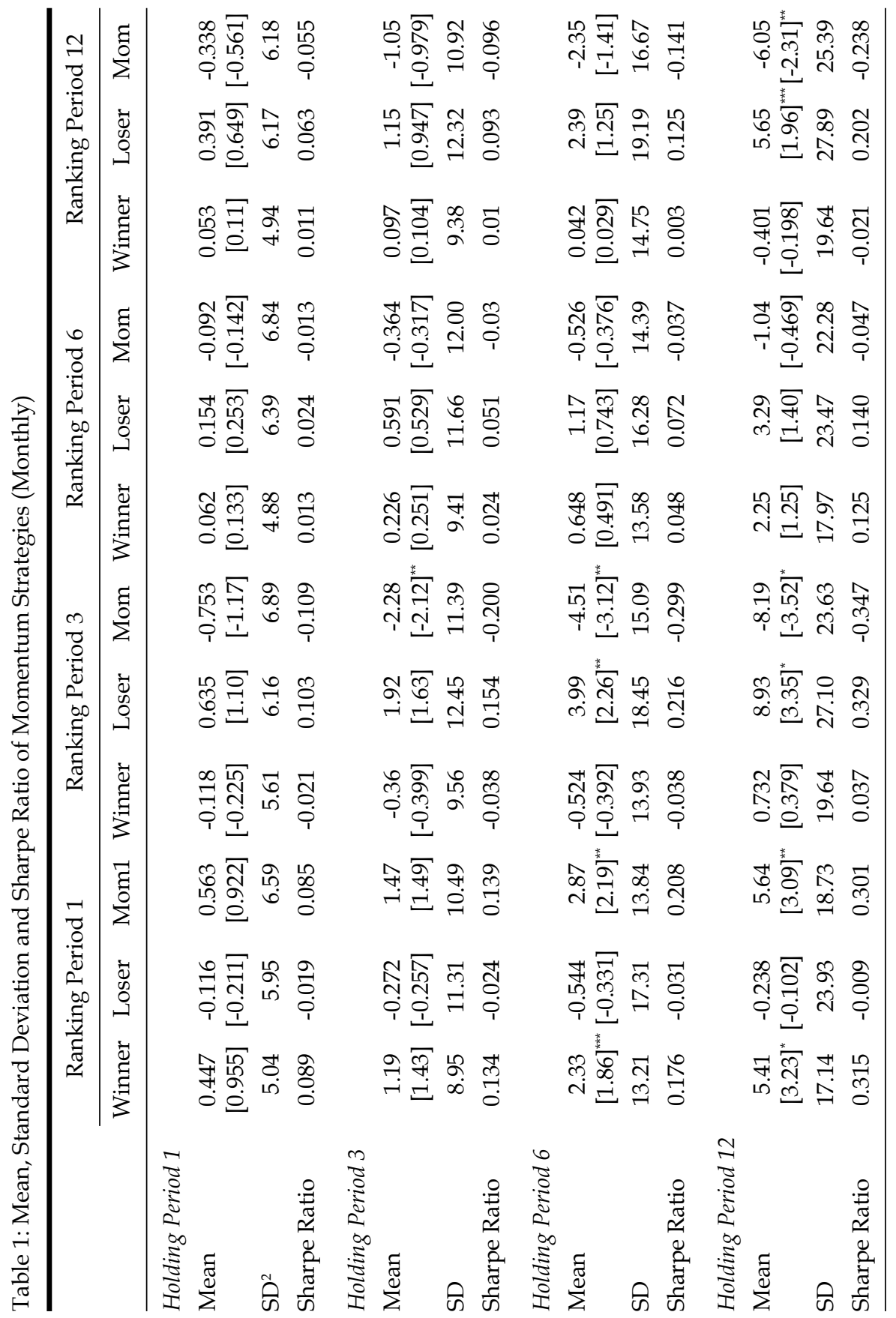


Momentum Strategies in Commodity Futures Market: Evidence from India

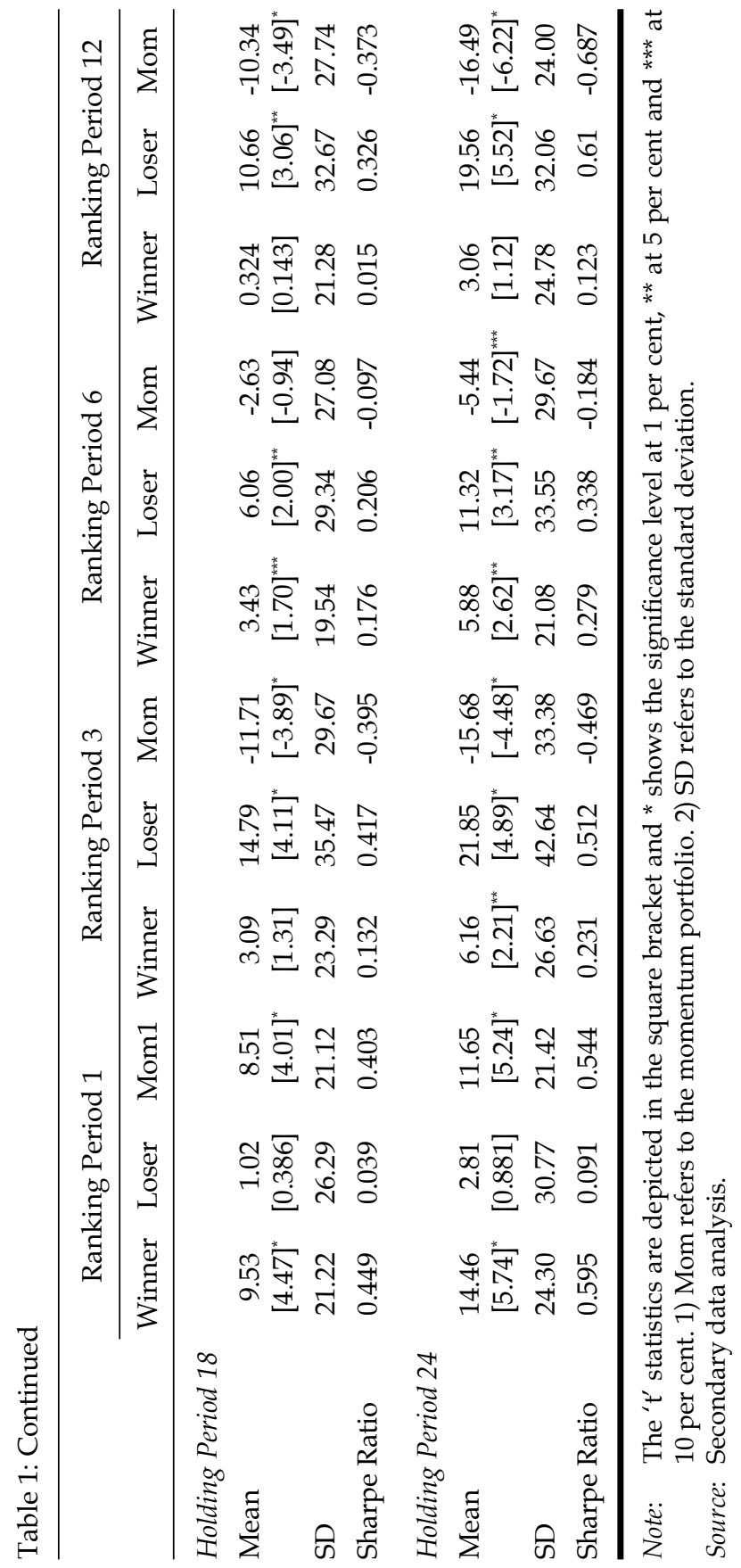




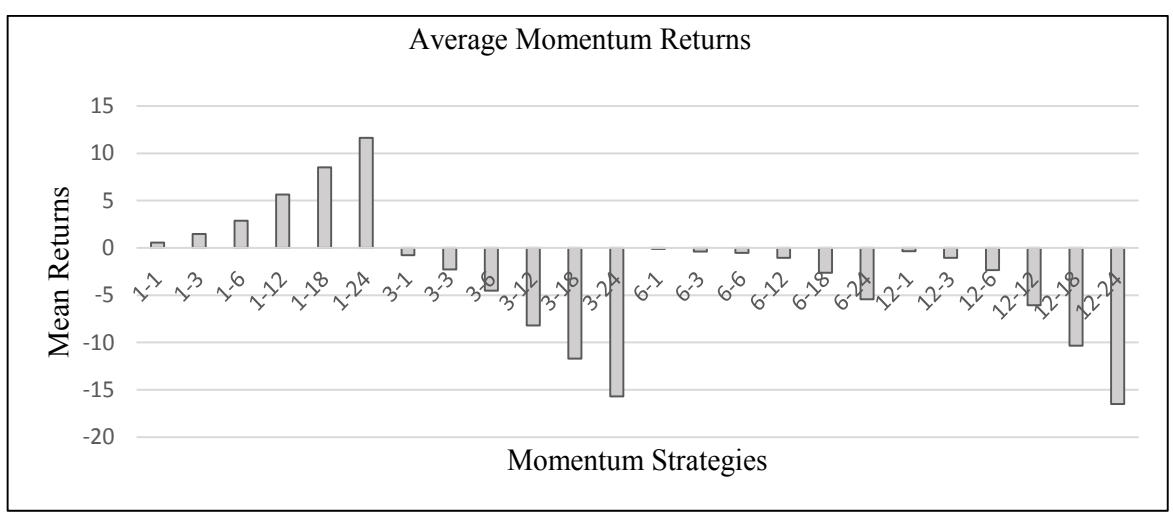

Figure 1: Average Momentum Returns over Different Momentum Strategies Source: Secondary data analysis.

monthly return of 11.65 per cent. This indicates that momentum profits increased with the holding period, and decreased with the ranking period, respectively. This result contradicted the findings of Erb and Harvey (2006), and Miffre and Rallis (2007), who stated that the momentum strategy with a 12-month ranking period, and a one-month holding period, was profitable in the commodity futures market

Table 1 shows that seven winner portfolios out of 24 momentum strategies yielded a positive and significant returns that ranged between the monthly return of 2.33 per cent to 14.46 per cent. In contrast, nine loser portfolios yielded a positive and significant returns that ranged between a low of 3.99 per cent to a high of 21.85 per cent, as depicted in Figure 2. Hence, it can be seen that the loser portfolios yielded a monthly average return of 11.42 per cent in comparison to the winner portfolios which yielded a 6.74 per cent return. This indicates that the loser portfolios outperformed the winner portfolios. However, in the case of the four profitable momentum strategies, profits were basically driven by the respective winner portfolios due to their positive and significant returns.

The standard deviation of the momentum strategies demonstrates that the momentum profits were not compensation for the risks. Table 1 shows that the standard deviation increases proportionately with the increase in momentum returns. For instance, in the group of ranking period one, the most profitable strategy was 1-24 which yielded the highest average monthly return of 11.65 per cent, and the highest standard deviation of 21.42. On the contrary, the lowest profitable strategy in the group of ranking period one was 1-1, with the lowest average return of 0.563 per cent, and the lowest standard deviation of 


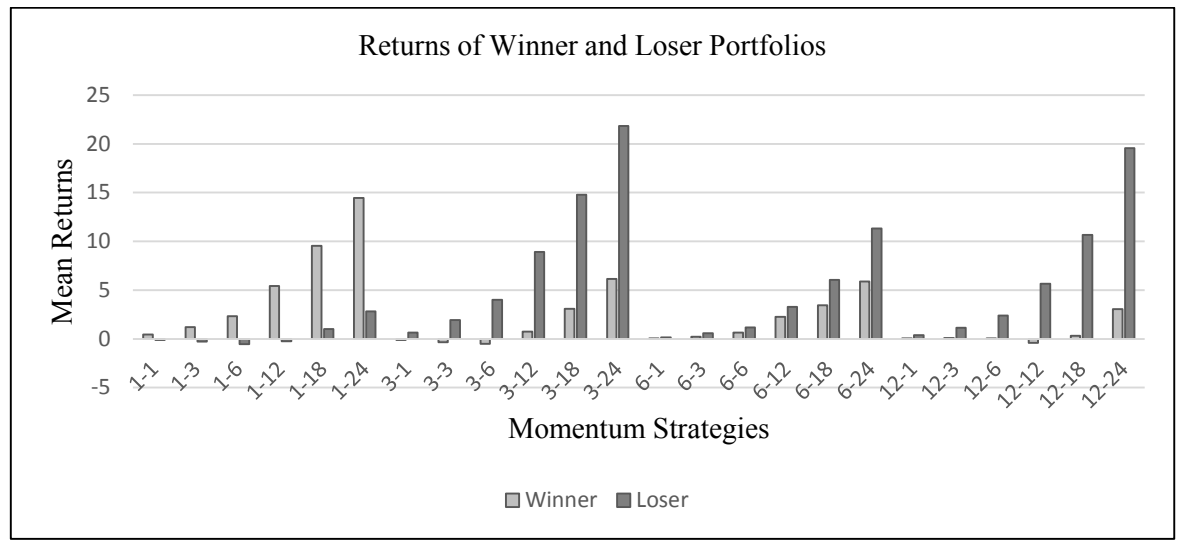

Figure 2: Average Returns of Winner and Loser Portfolios over Different Momentum Strategies

Source: Secondary data analysis.

6.59. Other ranking periods of three, six, and 12 months experienced similar results. These outcomes aligned with the findings of Miffre and Rallis (2007), and the normal market perception of higher returns associated with higher risks.

The Sharpe ratios shown in Table 1 showed the risk-adjusted performance of all the momentum strategies. In the one-month ranking group, the Sharpe ratio increased with the increase in momentum payoffs, ranging from 0.085 to 0.544 . For example, the most profitable strategy was the ranking group of 1-24; it showed the highest Sharpe ratio of 0.544 . On the contrary, the Sharpe ratio of the momentum strategies for the ranking periods of three, six, and 12 months were negative due to the negative returns given by these momentum strategies. Over the same period, the composite commodity, the stock and bond index indicated the Sharpe ratios of $0.038,0.102$ and 0.269 , respectively. This implies that the momentum strategy of the ranking period of one month in the commodity futures market performed better with respect to their risk-adjusted returns performance, as compared to the passive investment in equity, bond and commodity futures indices.

\subsubsection{Momentum Profits for Sub-Sample}

Table 2 displays the momentum payoffs of all the 24 strategies during the different time frames. These results highlight the impact of the commodity cycle on the consistency of the momentum profits in the future. 


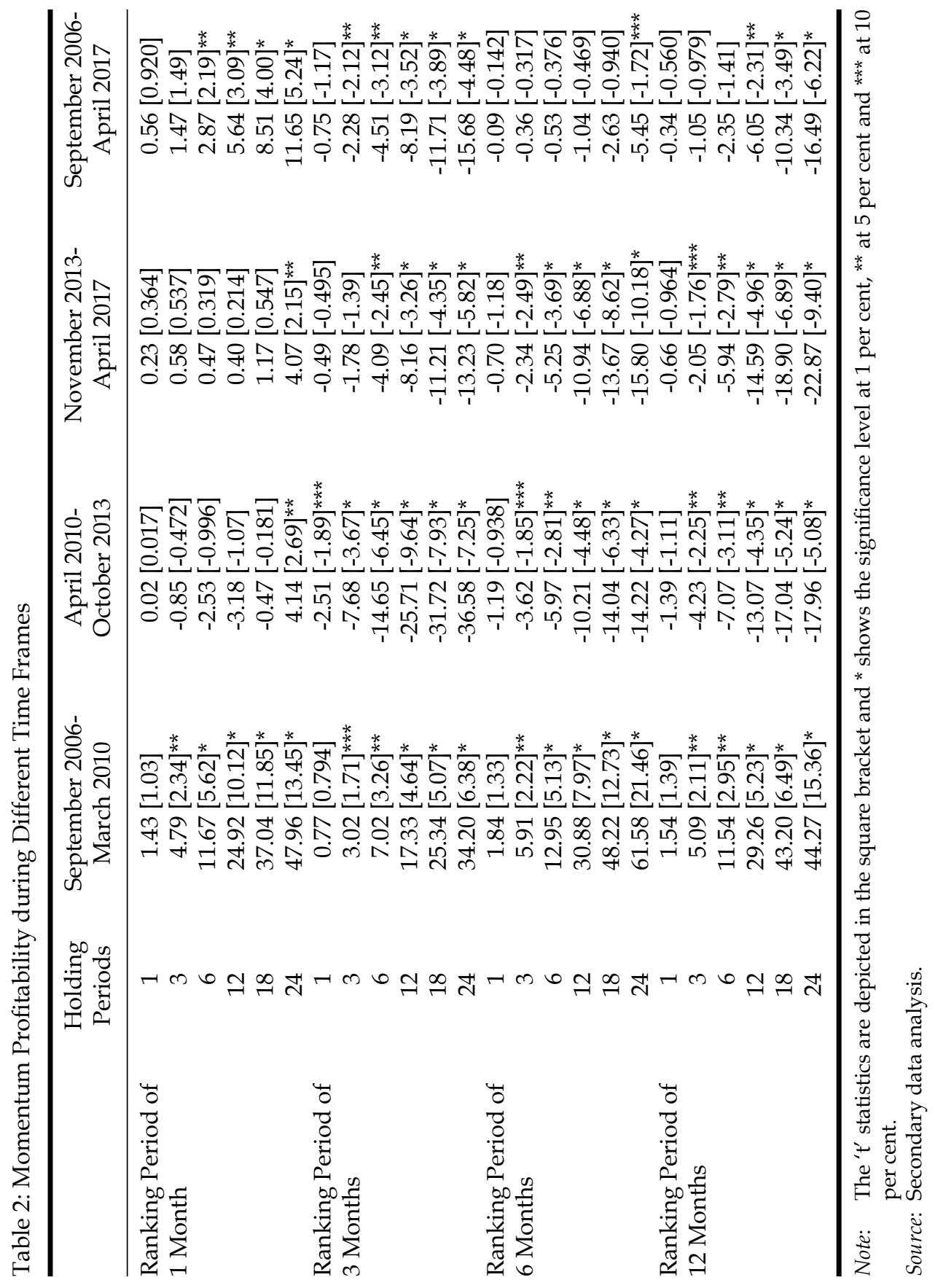


The whole sample period was divided into three equal sub-periods. The momentum risk-adjusted returns of the later period (November 2013-April 2017) was compared with the risk-adjusted returns of the earlier periods (September 2006-March 2010 and April 2010-October 2013). The results indicate that the momentum strategies of all the four ranking periods of the initial sub-period of September 2006-March 2010, yielded positive returns. This is depicted in Figure 3. On the contrary, all the momentum strategies for the subsequent sub-period, April 2010-October 2013, yielded negative returns except for the momentum strategy of 1-24, which had given positive and significant returns. Similarly, with the exception of the momentum strategies of the ranking period of one month, all the strategies with the ranking periods of three, six, and 12 months yielded negative and significant returns for the next sub-period of, November 2013-April 2017. The results indicate that the momentum strategies performed better for the earlier sub-period of September 2006-March 2010 as compared to the later sub-periods of April 2010-October 2013, and November 2013-April 2017. Furthermore, the profitable momentum strategies with the ranking period of one month, for the entire study period of September 2006-April 2017, yielded an average monthly return of 7.16 per cent. In contrast, the profitable momentum strategies with the ranking period of one month, for the sub-period of, September 2006-March 2010, yielded an average monthly return of 25.97 per cent. For the sub-periods of April 2010-October 2013, and November 2013-April 2017, only one momentum strategy (1-24)

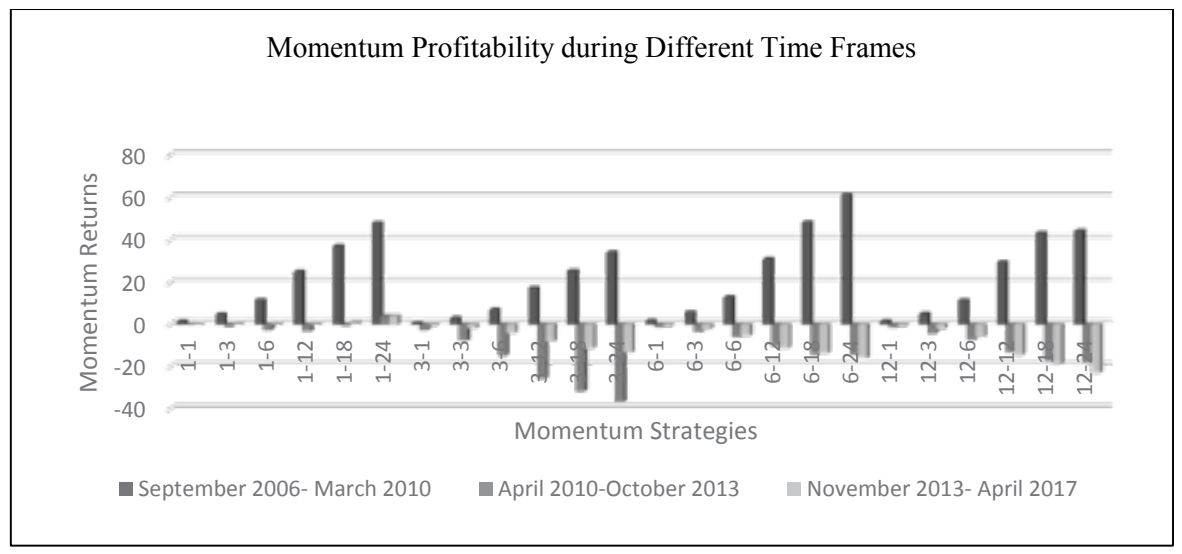

Figure 3: Average Returns of Momentum Strategies over Different Time-Frames Source: Secondary data analysis. 
had yielded a positive and significant monthly return of 4.14 per cent, and 4.07 per cent, respectively. A possible reason causing these returns is the commodity market being on a vicious downward trend/bear market, from 2012 to 2015. Nonetheless, the commodity market shot up to the bull phase from 2007 to 2010 (Cheng \& Xiong, 2014; Canuto, 2014; Sarhan, 2016). Therefore, during the later periods, from April 2010-October 2013, and November 2013-April 2017, the momentum payoffs reduced in comparison to the earlier period. This showed that the momentum profits were essentially time-varying. The bull period of 2007 to 2010 was the major driving force for the exceptionally high abnormal momentum profitability noted in the commodity futures market.

\subsubsection{Sensitivity Analysis of Momentum Profits}

Sensitivity analysis of the momentum profits was performed in two different ways. First, at the end of the month, the most distant maturity contract was used for rolling, and for compiling the future price series against the second nearest contract. Second, the rolling date was set to the 15th of the maturity month as opposed to the end of the month.

Results of the mean return, standard deviation, and the Sharpe ratio as shown in Table 3, suggest that the use of the most distant maturity contract, performed better than the use of the second nearest contract. The results verified that the returns of all the momentum strategies of the one-month ranking period were positive and significant, yielding an average monthly return of 10.19 per cent. The most profitable momentum strategy was 1-24, with the average return of 19.79 per cent, and the highest standard deviation of 28.99. In addition, the Sharpe ratio increased accordingly with the increase in momentum payoffs. All of these findings are consistent with the results shown in Table 1, where the second nearest contract was used as opposed to the most distant contract. Nonetheless, the magnitude of the momentum profitability was significantly high for the distant maturity contract. This implies that the use of a distant contract for the creation of futures time series was more profitable than the use of the nearest contract.

Table 3 also highlights a similar result to Table 1 when the 15th day of the maturity month was chosen as the rolling date. The results in Table 3 show that the returns of all of the momentum strategies with the one-month ranking period were positive and significant with an average monthly return of 10.98 per cent. Additionally, the most profitable strategy was the 1-24, with an average return of 24.21 per cent, and the 
Momentum Strategies in Commodity Futures Market: Evidence from India

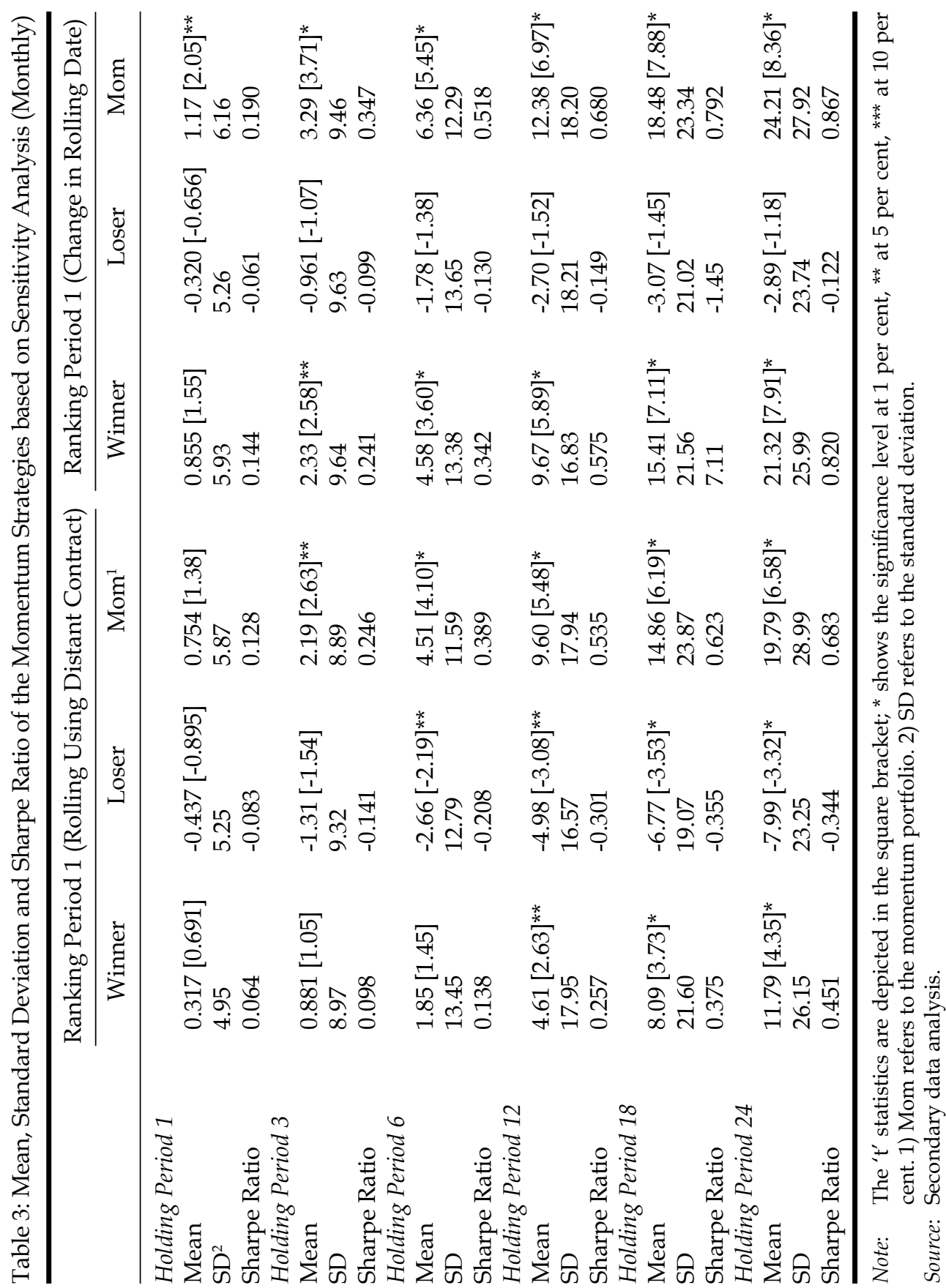


highest standard deviation of 27.92, thereby confirming that the highest momentum payoffs were associated with the highest risk. Similarly, the Sharpe ratio of the momentum strategies increased with the escalation of the momentum payoffs.

Figure 4 illustrates that compiling the future time series by using a distant maturity contract and setting the 15th day of the expiry month as a rolling date was highly profitable. This is different from using the nearest maturity contract, and the end of the month as a rolling date.

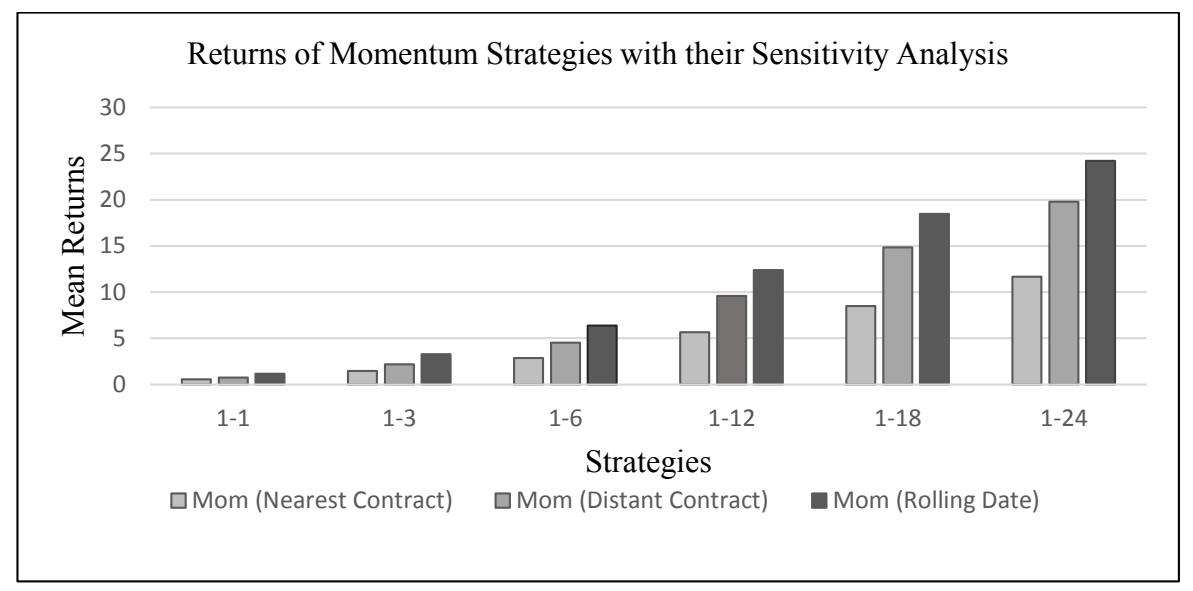

Figure 4: Average Returns of the Momentum Strategies with their Sensitivity Analysis

Source: Secondary data analysis.

\subsection{Risk-Based Analysis of Momentum Strategies}

The risk-based analysis of the momentum returns and their time-varying aspects are discussed in this section.

\subsubsection{Sensitivity Analysis of Momentum Payoffs against Market Risks}

Table 4 shows the abnormal performance (a) of momentum strategies and their sensitivity to the stock, bond, and commodity markets for the one-month ranking period.

From the table, it can be noted that two out of the six momentum strategies have a positive and significant beta for the bond index, and one of the momentum strategies has a positive and significant beta for the Nifty index. The remainder of the momentum returns was neutral 
to the risk of the Nifty index. The results show that out of four profitable momentum strategies, two strategies of 18 and 24 months holding periods had yielded positive and significant abnormal returns $(\alpha)$.

Table 4: Risk-Based Performance of Momentum Strategies

(Ranking Period of One Month)

\begin{tabular}{|c|c|c|c|c|}
\hline & Parameters & Winner & Loser & Momentum \\
\hline $\begin{array}{l}\text { Holding Period } \\
\text { of } 1 \text { Month }\end{array}$ & $\begin{array}{c}\mathrm{A} \\
\beta_{S} \\
\beta_{B} \\
\beta_{C} \\
\text { Adjusted } R^{2}\end{array}$ & $\begin{array}{c}0.512[0.391] \\
-0.0006[-0.0094] \\
-0.096[-0.582] \\
0.099[1.17] \\
21.22 \%\end{array}$ & $\begin{array}{c}2.52[1.65] \\
-0.052[-0.656] \\
0.255[1.33] \\
0.191[1.93]^{* * *} \\
25.45 \%\end{array}$ & $\begin{array}{c}-2.01[-1.18] \\
0.051[0.579] \\
-0.350[-1.64] \\
-0.092[-0.829] \\
35.85 \%\end{array}$ \\
\hline $\begin{array}{l}\text { Holding Period } \\
\text { of } 3 \text { Months }\end{array}$ & $\begin{array}{c}\mathrm{A} \\
\beta_{S} \\
\beta_{B} \\
\beta_{C} \\
\text { Adjusted } R^{2}\end{array}$ & $\begin{array}{c}2.22[0.992] \\
0.235[2.03]^{\star *} \\
-0.339[-1.21] \\
0.250[1.71]^{\star * *} \\
23.54 \%\end{array}$ & $\begin{array}{c}4.95[1.70]^{* * *} \\
0.076[0.502] \\
0.462[1.27] \\
0.255[1.34] \\
20.87 \%\end{array}$ & $\begin{array}{c}-2.74[-1.02] \\
0.159[1.15] \\
-0.801[-2.39]^{* *} \\
-0.005[-0.029] \\
29.87 \%\end{array}$ \\
\hline $\begin{array}{l}\text { Holding Period } \\
\text { of } 6 \text { Months }\end{array}$ & $\begin{array}{c}\mathrm{A} \\
\beta_{S} \\
\beta_{B} \\
\beta_{C} \\
\text { Adjusted } R^{2}\end{array}$ & $\begin{array}{c}5.55[1.58] \\
-0.004[-0.023] \\
0.214[0.493] \\
0.272[1.19] \\
27.85 \%\end{array}$ & $\begin{array}{c}6.12[1.34] \\
-0.119[-0.512] \\
0.874[1.54] \\
0.259[0.868] \\
26.15\end{array}$ & $\begin{array}{c}-0.567[-0.155] \\
0.115[0.617] \\
-0.659[-1.45] \\
0.013[0.055] \\
33.32 \%\end{array}$ \\
\hline $\begin{array}{l}\text { Holding Period } \\
\text { of } 12 \text { Months }\end{array}$ & $\begin{array}{c}\mathrm{A} \\
\beta_{S} \\
\beta_{B} \\
\beta_{C} \\
\text { Adjusted } R^{2}\end{array}$ & $\begin{array}{c}11.59[2.50]^{* *} \\
-0.081[-0.346] \\
0.746[1.31] \\
0.271[0.903] \\
31.95 \%\end{array}$ & $\begin{array}{c}6.22[0.960] \\
-0.170[-0.517] \\
1.07[1.34] \\
0.088[0.210] \\
\quad 22.88 \%\end{array}$ & $\begin{array}{c}5.37[1.05] \\
0.089[0.343] \\
-0.325[-0.519] \\
0.183[0.554] \\
20.54 \%\end{array}$ \\
\hline $\begin{array}{l}\text { Holding Period } \\
\text { of } 18 \text { Months }\end{array}$ & $\begin{array}{c}\alpha \\
\beta_{S} \\
\beta_{B} \\
\beta_{C} \\
\text { Adjusted } R^{2}\end{array}$ & $\begin{array}{c}17.06[2.94]^{* *} \\
0.133[0.428] \\
0.446[0.628] \\
0.533[1.42] \\
32.74 \%\end{array}$ & $\begin{array}{c}4.77[0.652] \\
-0.105[-0.269] \\
0.365[0.409] \\
0.296[0.626] \\
27.23 \%\end{array}$ & $\begin{array}{c}12.29[2.16]^{* *} \\
0.239[0.763] \\
0.081[0.113] \\
0.237[0.626] \\
36.47 \%\end{array}$ \\
\hline $\begin{array}{l}\text { Holding Period } \\
\text { of } 24 \text { Months }\end{array}$ & $\begin{array}{c}\alpha \\
\beta_{S} \\
\beta_{B} \\
\beta_{C} \\
\text { Adjusted } R^{2}\end{array}$ & $\begin{array}{c}23.94[3.44]^{*} \\
-0.115[-0.296] \\
0.726[0.854] \\
0.789[1.67]^{* * *} \\
26.56 \%\end{array}$ & $\begin{array}{c}-5.79[-0.658] \\
-0.732[-1.49] \\
-0.896[-0.835] \\
0.259[0.434] \\
29.45 \%\end{array}$ & $\begin{array}{c}29.72[5.15]^{*} \\
0.617[1.91]^{* * *} \\
1.62[2.30]^{* *} \\
0.531[1.36] \\
39.14 \%\end{array}$ \\
\hline
\end{tabular}

Note: The ' $\mathrm{t}$ ' statistics are depicted in the square bracket and * shows the significance level at 1 per cent, ** at 5 per cent and ${ }^{* * *}$ at 10 per cent.

Source: Secondary data analysis. 
On average, the monthly abnormal returns of the profitable strategies were 21.00 per cent, ranging between 12.29 per cent for the strategy of 1-18 to 29.72 per cent for the strategy of 1-24. Hence, the returns of the momentum strategies of longer holding periods were not just compensations for the different market risk factors; there were also indications that long-term investment horizons could earn abnormal returns by using momentum strategies in the commodity futures market. Clearly, the abnormal returns of the momentum strategies were driven by the winner portfolios due to their significant alpha values.

\subsubsection{Time-Varying Risk-Based Analysis of Momentum Strategies}

As a robustness check, it is essential to analyse whether the returns of the momentum strategies were due to exposure to the time-varying risks. To assess this, the time-varying abnormal performance $(\alpha)$, and the risks were measured based on the vector of the business cycle variables.

Both the alpha of all the information variables, and the probability value of all the hypotheses were reported in Table 5 . The results demonstrate that five out of six strategies had a significant timedependent conditional alpha $\left(\alpha_{1}\right)$, and all the six strategies had a significant time-dependent conditional beta $\left(\beta_{1}\right)$. Further, all the strategies showed the joint significance for both the conditional alpha and beta. The application of the model shown in Equation (5) was therefore, justified with respect to the measure of time-varying alpha and beta. The negative values of the monthly conditional measure of the abnormal returns $\left(\alpha_{0}\right)$ of all the strategies indicated that momentum strategies were unable to give abnormal performance when the vector of the lagged macroeconomic variables were used for the business cycle. This means that the abnormal returns of the momentum strategies were essentially, time-varying. The current result contradicted the findings of Miffre and Rallis (2007), who noted that momentum returns can be defined by the time-varying risks.

\subsection{Transaction Costs Estimation for Momentum Strategies}

It is ordinarily assumed that the abnormal profitability of the momentum strategies could be eroded by the transaction costs incurred in implementing these strategies (Lesmond et al., 2004). In this regard, Fuertes et al. (2010) computed the net momentum returns by considering the conservative estimates of the transaction cost of 0.033 per cent as 
Momentum Strategies in Commodity Futures Market: Evidence from India

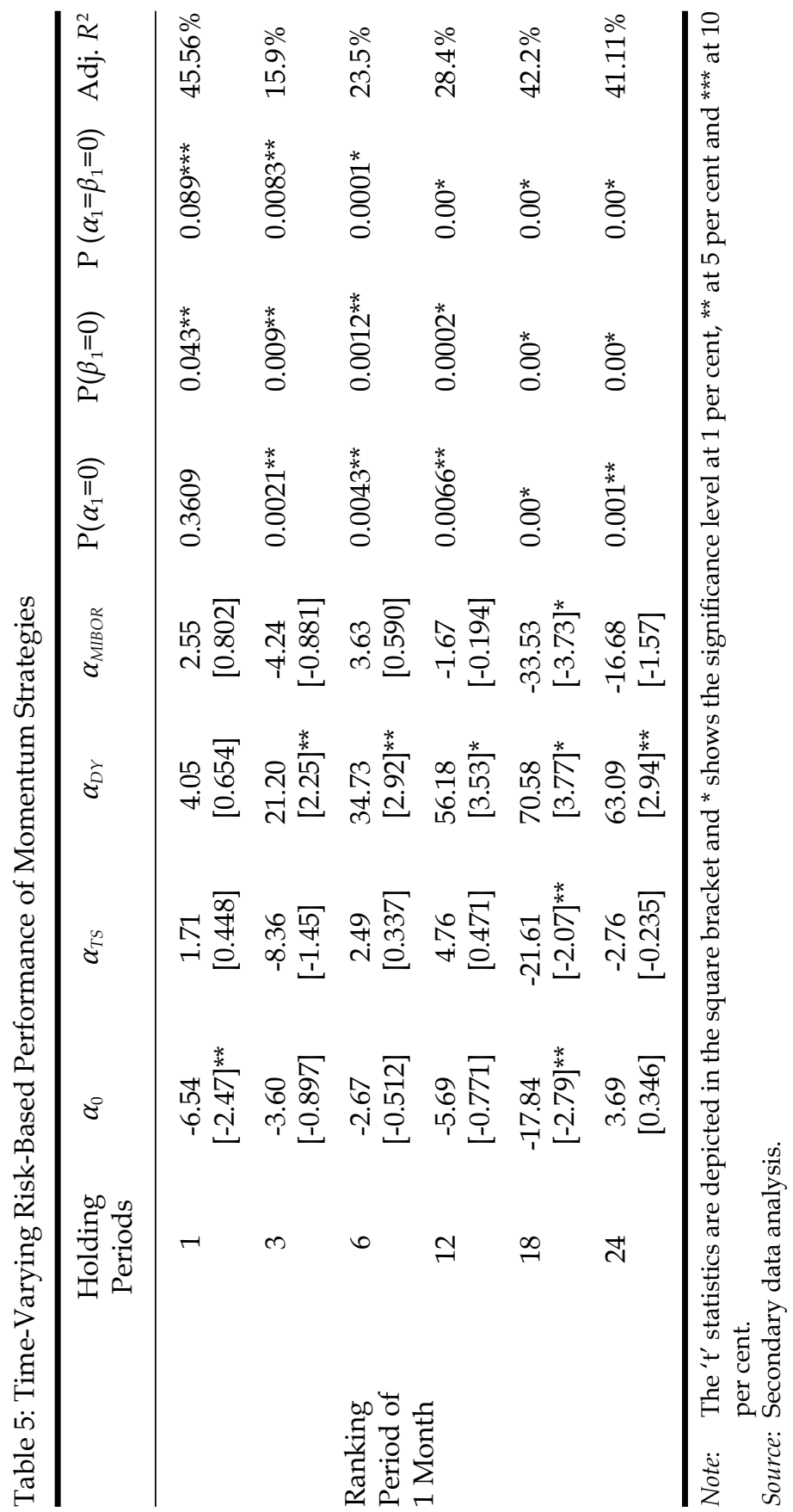


declared by Locke and Venkatesh (1997). They suggested that the rolling of contracts, the change in the constituents of the active portfolio, and the active rebalancing of the portfolio served as the key factors affecting the portfolio turnover, and consequently, the momentum profits.

In the present study, more significance was given to the trading costs incurred while performing the monthly rebalancing of the constituents in order to get the equal weights. This is because all the 13 commodity futures were included in the portfolio for all of the rebalancing months. Moreover, the position and weights of the constituents were constantly changed for all the months in order to achieve equal weights for both the winner and the loser portfolios. The portfolio turnover, and the net momentum returns were estimated using Equations (6), (7) and (8).

The results presented in Table 6 clearly indicate that transaction costs could not erode the positive momentum returns although the transaction costs had reduced the magnitude of the momentum payoffs. On average, the momentum strategies earned a monthly net return of 6.42 per cent (annualised net return of 57.67 per cent), at a transaction cost of 0.033 per cent. At the highest level of the transaction cost of 0.146 per cent, as reported by Shen et al. (2007), these strategies had also earned a monthly average net return of 5.67 per cent (annualised net return of 50.93 per cent). It indicates that abnormal returns of momentum strategies are sufficient to meet the highest level of transection cost.

Table 6: Portfolio Turnover and the Net Momentum Returns of the Profitable Momentum Strategies

\begin{tabular}{lccccc}
\hline & $\begin{array}{c}\text { Holding } \\
\text { Period }\end{array}$ & $\begin{array}{c}\text { Momentum } \\
\text { Returns } \\
(\%)\end{array}$ & $\begin{array}{c}\text { Portfolio } \\
\text { Turnover } \\
(\%)\end{array}$ & $\begin{array}{c}\text { Net } \\
\text { Momentum } \\
\text { Returns } \\
(0.033 \%)\end{array}$ & $\begin{array}{c}\text { Net } \\
\text { Momentum } \\
\text { Returns } \\
(0.146 \%)\end{array}$ \\
\hline & 6 & 2.87 & 0.973 & 1.61 & 1.42 \\
Ranking Period & 12 & 5.64 & 0.973 & 4.86 & 4.29 \\
of 1 Month & 18 & 8.51 & 0.973 & 7.98 & 7.05 \\
& 24 & 11.65 & 0.973 & 11.23 & 9.91 \\
\hline
\end{tabular}

\subsection{Momentum Portfolio: Diversification and Inflation Hedge}

Table 7 displays the correlation between the momentum returns and the returns of the stock, bond, and commodity indices. The returns of all the profitable momentum strategies had a positive and insignificant 
Table 7: Correlation of Momentum Portfolios with Nifty Index, CCIL Bond Index, Composite Commodity Index and Inflation Index

\begin{tabular}{lccccc}
\hline & $\begin{array}{c}\text { Holding } \\
\text { Periods }\end{array}$ & $\begin{array}{c}\text { Commodity } \\
\text { Index }\end{array}$ & $\begin{array}{c}\text { NIFTY } \\
\text { Stock Index }\end{array}$ & $\begin{array}{c}\text { CCIL Liquid } \\
\text { Bond Index }\end{array}$ & $\begin{array}{c}\text { Inflation } \\
\text { Index }\end{array}$ \\
\hline & 6 & 0.0783 & 0.0630 & -0.0923 & $-0.2574^{* *}$ \\
Ranking Period & 12 & 0.0650 & 0.0322 & -0.1091 & $-0.3678^{* *}$ \\
of 1 Month & 18 & 0.0349 & 0.0633 & -0.1168 & $-0.4558^{* *}$ \\
& 24 & 0.0411 & 0.1991 & -0.0352 & $-0.5578^{* *}$ \\
\hline
\end{tabular}

Note: * Shows the significance level at 1 per cent and ** at 5 per cent.

Source: Secondary data analysis.

correlation with the commodity and stock indices. The average correlation between the momentum returns and the stock returns was 0.0894 , which ranged between 0.0322 for the strategy of 1-12 to 0.1991 for the strategy of 1-24. In contrast, the correlation of the momentum returns of all the four strategies with the bond index was negative and insignificant. These results confirmed that commodity futures can be treated as an excellent means for portfolio diversification, in addition, to earning an abnormal return.

Table 7 also shows the momentum returns, and the inflation index correlation. The results demonstrate the negative and significant correlation of the momentum returns with the inflation index for all the four profitable momentum strategies. These results suggest that the momentum portfolios cannot be used as a hedge against inflation. Hence, the abnormal returns of the momentum strategies, and their diversification benefits led to the loss of the basic inflation hedging potential. These findings were consistent with Erb and Harvey (2006), and Miffre and Rallis (2007).

\section{Conclusions}

This study had analysed the time-varying conditional profitability of 24 momentum strategies for the commodity futures market of India. The results confirmed the exceptionally high alpha generating potentials of the momentum strategies. The strategies that were based on the ranking period of the nearest month were more profitable in the commodity market. Moreover, investors with a long-term investment horizon could earn a superior abnormal return by utilising the momentum strategies in the commodity market. The returns of the winner and loser portfolios 
also indicated the price reversal in the dataset. This showed that the loser portfolios outperformed the winner portfolios. The estimation of the average monthly net returns further showed that the abnormal profitability of the momentum strategies could not be eroded by transaction costs incurred while implementing these strategies.

The sensitivity analysis of the momentum payoffs further confirmed that the different methods of compiling the future price series which were based on the change in rolling date, and the use of distant maturity contracts, had yielded exceptionally high average returns when compared to the typical method of compiling the future time series. Subsequently, the sub-sample analysis of the momentum payoffs, and the time-varying analysis of the conditional beta and alpha, indicated that the abnormal performance of the momentum strategies was due to time-varying factor. The results had also affirmed that a momentum portfolio could not be used as a hedge against inflation risks. Nonetheless, the exceptionally high abnormal returns of the momentum strategies compensated for the loss in inflation hedging potentials, making it as a suitable tool for portfolio diversification.

The findings of this study are crucial for global and domestic investors. They offer insights to the investors in understanding the tactical allocation of commodity futures so as to earn abnormal returns, as well as, its use as a tool for portfolio diversification. The abnormal momentum returns may significantly influence the investment decision of institutional investors, and professional money managers, such as mutual funds, alternative investment funds, hedge funds, and commodity pool operators. Based on the outcome of this study, policymakers may consider designing a policy framework which can deliver the commodity futures in a mainstream investment vehicle for the creation of a well-diversified investment portfolio. Doing so can help the market to earn high abnormal returns particularly when using commodity futures as a price risk management tool.

It is thus concluded that the momentum strategies which were designed by using the historical performance of 13 highly liquid commodity futures contracts, produced exceptionally high abnormal returns. They were essentially defined by the commodity cycle. Nevertheless, future research should investigate the robustness of the high abnormal returns by including the medium and less liquid commodity futures contracts for the creation of the momentum strategies. Future research may also undertake to validate the consistency of these returns by using forecasting techniques. 


\section{References}

Asness, C.S., Moskowitz, T.J., \& Pedersen, L.H. (2013). Value and momentum everywhere. The Journal of Finance, 68(3), 929-985. http://dx.doi.org/ 10.1111/jofi.12021

Avramov, D., Cheng, S., \& Hameed, A. (2016). Time-varying liquidity and momentum profits. Journal of Financial and Quantitative Analysis, 51(6), 18971923. http://dx.doi.org/10.2139/ssrn.2289745

Barberis, N., Shleifer, A., \& Vishny, R. (1998). A model of investor sentiment. Journal of Financial Economics, 49(3), 307-343. http://dx.doi.org/10.1016/ S0304-405X(98)00027-0

Bianchi, R., Drew, M., \& Fan, J.H. (2015). Microscopic momentum in commodity futures (Discussion Paper Finance). Australia: Department of Accounting, Finance and Economics, Griffith University.

Bodie, Z., \& Rosansky, V.I. (1980). Risk and return in commodity futures. Financial Analysts Journal, 36(3), 27-39. http://dx.doi.org/10.2469/faj.v36. n3.27

Canuto, O. (2014) The commodity super cycle: Is this time different? Poverty Reduction and Economic Management Network, June (150), 1-3.

Chaves, D.B. (2012). Eureka! A momentum strategy that also works in Japan. (January 9). http://dx.doi.org/10.2139/ssrn.1982100

Cheng, I.H., \& Xiong, W. (2014). The financialization of commodity markets. Annual Review of Financial Economics, 6, 419-441. http://dx.doi.org/ 10.1146/annurev-financial-110613-034432

Chordia, T., \& Shivakumar, L. (2002). Momentum, business cycle, and timevarying expected returns. The Journal of Finance, 57(2), 985-1019. http:// dx.doi.org/10.1111/1540-6261.00449

Christopherson, J.A., Ferson, W.E., \& Glassman, D.A. (1998). Conditioning manager alphas on economic information: Another look at the persistence of performance. The Review of Financial Studies, 11(1), 111-142. http:// dx.doi.org/10.1093/rfs/11.1.0111

Chui, A.C., Titman, S., \& Wei, K.J. (2010). Individualism and momentum around the world. The Journal of Finance, 65(1), 361-392. http://dx.doi.org/10.1111/ j.1540-6261.2009.01532.x

Daniel, K., Hirshleifer, D., \& Subrahmanyam, A. (1998). Investor psychology and security market under- and overreactions. The Journal of Finance, 53(6), 1839-1885. http:// dx.doi.org/10.1111/0022-1082.00077

Daskalaki, C., \& Skiadopoulos, G. (2011). Should investors include commodities in their portfolios after all? New evidence. Journal of Banking $\mathcal{E}$ Finance, 35(10), 2606-2626. http://dx.doi.org/10.1016/j.jbankfin.2011.02.022

DeMiguel, V., Garlappi, L., \& Uppal, R. (2009). Optimal versus naive diversification: How inefficient is the $1 / \mathrm{N}$ portfolio strategy? The Review of Financial Studies, 22(5), 1915-1953. http://dx.doi.org/10.1093/rfs/hhm075 
Erb, C.B., \& Harvey, C.R. (2006). The strategic and tactical value of commodity futures. Financial Analysts Journal, 62(2), 69-97. http://dx.doi.org/10.2469/ faj.v62.n2.4084

Fama, E.F. (1970). Efficient capital markets: A review of theory and empirical work. The Journal of Finance, 25(2), 383-417.

Fama, E.F., \& French, K.R. (2012). Size, value, and momentum in international stock returns. Journal of Financial Economics, 105(3), 457-472. http://dx.doi. org/10.1016/j.jfineco.2012.05.011

Ferson, W.E., \& Schadt, R.W. (1996). Measuring fund strategy and performance in changing economic conditions. The Journal of Finance, 51(2), 425-461. http://dx.doi.org/10.1111/j.1540-6261.1996.tb02690.x

Fuertes, A.M., Miffre, J., \& Rallis, G. (2010). Tactical allocation in commodity futures markets: Combining momentum and term structure signals. Journal of Banking \& Finance, 34(10), 2530-2548. http://dx.doi.org/10.1016/j. jbankfin.2010.04.009

Gorton, G., \& Rouwenhorst, K.G. (2006). Facts and fantasies about commodity futures. Financial Analysts Journal, 62(2), 47-68. http://dx.doi.org/10.2469/ faj.v62.n2.4083

Gorton, G.B., Hayashi, F., \& Rouwenhorst, K.G. (2013). The fundamentals of commodity futures returns. Review of Finance, 17(1), 35-105. http://dx.doi. org/10.1093/rof/rfs019

Griffin, J.M., Ji, X., \& Martin, J.S. (2003). Momentum investing and business cycle risk: Evidence from pole to pole. The Journal of Finance, 58(6), 2515-2547. http://dx.doi.org/10.1046/j.1540-6261.2003.00614.x

Grundy, B.D., \& Martin, J.S.M. (2001). Understanding the nature of the risks and the source of the rewards to momentum investing. The Review of Financial Studies, 14(1), 29-78. http://dx.doi.org/10.1093/rfs/14.1.29

Hicks, J.R. (1939). Value and capital. Cambridge, England: Oxford University Press.

Hong, H., Lim, T., \& Stein, J.C. (2000). Bad news travels slowly: Size, analyst coverage, and the profitability of momentum strategies. The Journal of Finance, 55(1), 265-295. http://dx.doi.org/10.1111/0022-1082.00206

Jaiswal, R., \& Uchil, R. (2016). An empirical analysis of inflation hedging potential of commodity futures: A regime switching approach. Indore Management Journal, 8(2), 33-48.

Jaiswal, R., \& Uchil, R. (2018a). An analysis of diversification benefits of commodity futures using Markov regime-switching approach. Afro-Asian Journal of Finance and Accounting, 8(1), 20-47. http://dx.doi.org/10.1504/ AAJFA.2018.089193

Jaiswal, R., \& Uchil, R. (2018b). An Analysis of Gold Futures as an Alternative Asset: Evidence from India. International Journal of Economics and Financial Issues, 8(6), 144-150

Jegadeesh, N., \& Titman, S. (1993). Returns to buying winners and selling losers: Implications for stock market efficiency. The Journal of Finance, 48(1), 65-91. http://dx.doi.org/10.1111/j.1540-6261.1993.tb04702.x 
Jegadeesh, N., \& Titman, S. (2001). Profitability of momentum strategies: An evaluation of alternative explanations. The Journal of Finance, 56(2), 699-720. http://dx.doi.org/10.1111/0022-1082.00342

Jensen, G.R., Johnson, R.R., \& Mercer, J.M. (2002). Tactical asset allocation and commodity futures. The Journal of Portfolio Management, 28(4), 100-111. http://dx.doi.org/10.3905/jpm.2002.319859

Johnson, T.C. (2002). Rational momentum effects. The Journal of Finance, 57(2), 585-608. http://dx.doi.org/10.1111/1540-6261.00435

Keim, D.B. (2003). The cost of trend chasing and the illusion of momentum profits. Retrieved from https://repository.upenn.edu/fnce_papers/2

Keynes, J.M. (1930). Treatise on money. (Vol. 2) London: Macmillan.

Kolb, R.W. (1992). Is normal backwardation normal? The Journal of Futures Markets (1986-1998), 12(1), 75-91.

Korajczyk, R.A., \& Sadka, R. (2004). Are momentum profits robust to trading costs? The Journal of Finance, 59(3), 1039-1082. http://dx.doi.org/10.1111/ j.1540-6261.2004.00656.x

Kostakis, A., Panigirtzoglou, N., \& Skiadopoulos, G. (2011). Market timing with option-implied distributions: A forward-looking approach. Management Science, 57(7), 1231-1249. http://dx.doi.org/10.1287/mnsc.1110.1346

Lee, C.M., \& Swaminathan, B. (2000). Price momentum and trading volume. The Journal of Finance, 55(5), 2017-2069. http://dx.doi.org/10.1111/00221082.00280

Leite, P., Cortez, M.C., \& Armada, M.R. (2009). Measuring fund performance using multi-factor models: Evidence for the Portuguese market. International Journal of Business, 14(3), 175-197.

Lesmond, D.A., Schill, M.J., \& Zhou, C. (2004). The illusory nature of momentum profits. Journal of Financial Economics, 71(2), 349-380. http://dx.doi.org/ 10.1016/S0304-405X(03)00206-X

Li, X., Miffre, J., Brooks, C., \& O'Sullivan, N. (2008). Momentum profits and time-varying unsystematic risk. Journal of Banking \& Finance, 32(4), 541-558. http://dx.doi.org/10.1016/j.jbankfin.2007.03.014

Lobão, J., \& Lopes, C.D.M. (2014). Momentum strategies in the Portuguese stock market, Aestimatio, (8), 68-89.

Locke, P.R., \& Venkatesh, P.C. (1997). Futures market transaction costs. The Journal of Futures Markets (1986-1998), 17(2), 229-245.

Marshall, B.R., Nguyen, N.H., \& Visaltanachoti, N. (2012). Commodity liquidity measurement and transaction costs. The Review of Financial Studies, 25(2), 599-638. http://dx.doi.org/10.1093/rfs/hhr075

Miffre, J. (2000). Normal backwardation is normal. Journal of Futures Markets: Futures, Options, and Other Derivative Products, 20(9), 803-821. http://dx.doi. org/10.1002/1096-9934(200010)20:9\%3C803::AID-FUT1\%3E3.0.CO;2-Q

Miffre, J., \& Rallis, G. (2007). Momentum strategies in commodity futures markets. Journal of Banking \& Finance, 31(6), 1863-1886. http://dx.doi.org/ 10.1016/j.jbankfin.2006.12.005 
Moskowitz, T.J., \& Grinblatt, M. (1999). Do industries explain momentum? The Journal of Finance, 54(4), 1249-1290. http://dx.doi.org/10.1111/00221082.00146

Moskowitz, T.J., Ooi, Y.H., \& Pedersen, L.H. (2012). Time series momentum. Journal of Financial Economics, 104(2), 228-250. http://dx.doi.org/10.1016/j. jfineco.2011.11.003

Narayan, P.K., Ahmed, H.A., \& Narayan, S. (2015). Do momentum-based trading strategies work in the commodity futures markets? Journal of Futures Markets, 35(9), 868-891. http:/ /dx.doi.org/10.1002/fut.21685

Page, D., Britten, J., \& Auret, C.J. (2013). Momentum and liquidity on the Johannesburg Stock Exchange. International Journal of Economics and Finance Studies, 5(1), 56-73.

Rouwenhorst, K.G. (1998). International momentum strategies. The journal of finance, 53(1), 267-284. http://dx.doi.org/10.1111/0022-1082.95722

Sarhan, A. (2016). New commodity super cycle? Forbes. Retrieved from http:// www.forbes.com/sites/adamsarhan/2016/06/08/new-commodity-supercycle/\# 1d0ef05b1edc

Sharma, A., Ramana, L.V., Thaker, K., \& Rastogi, S.K. (2014). Performance of Indian commodity futures market: An analysis, In O.M. Lehner, \& Harrison, R., ACRN Proceedings in Finance and Risk Series '13: Proceedings of the 13th FRAP Conference in Cambridge (pp. 2-20). Austria: ACRN Publishing House.

Shen, Q., Szakmary, A.C., \& Sharma, S.C. (2007). An examination of momentum strategies in commodity futures markets. Journal of Futures Markets: Futures, Options, and Other Derivative Products, 27(3), 227-256. http://dx.doi. org/10.1002/fut.20252

Tan, Y.M., \& Cheng, F.F. (2019). Industry-and liquidity-based momentum in Australian equities. Financial Innovation, 5(1), 43-61. http://dx.doi.org/ 10.1186/s40854-019-0155-z

Van der Hart, J., Slagter, E., \& Van Dijk, D. (2003). Stock selection strategies in emerging markets. Journal of Empirical Finance, 10(1-2), 105-132. http:// dx.doi.org/10.1016/S0927-5398(02)00022-1

Zaremba, A. (2016). Strategies based on momentum and term structure in financialized commodity markets. Business and Economics Research Journal, 7(1), 31-46. http://dx.doi.org/10.2139/ssrn.2469407 